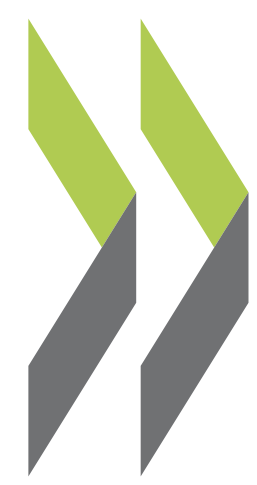

OECD Economics Department Working Papers No. 1323

A bird-eye view of Costa Rica's transport infrastructure

Mauro Pisu, Federico Villalobos 
Organisation de Coopération et de Développement Économiques

Organisation for Economic Co-operation and Development

03-Aug-2016

ECONOMICS DEPARTMENT

English - Or. English

\section{A BIRD-EYE VIEW OF COSTA RICA'S TRANSPORT INFRASTRUCTURE}

ECONOMICS DEPARTMENT WORKING PAPERS No. 1323

By Mauro Pisu and Federico Villalobos

OECD Working Papers should not be reported as representing the official views of the OECD or of its member countries. The opinions expressed and arguments employed are those of the author(s).

Authorised for publication by Robert Ford, Deputy Director, Country Studies Branch, Economics Department.

All Economics Department Working Papers are available at www.oecd.org/eco/workingpapers

JT03399610

Complete document available on OLIS in its original format

This document and any map included herein are without prejudice to the status of or sovereignty over any territory, to the delimitation of international frontiers and boundaries and to the name of any territory, city or area. 
OECD Working Papers should not be reported as representing the official views of the OECD or of its member countries. The opinions expressed and arguments employed are those of the author(s).

Working Papers describe preliminary results or research in progress by the author(s) and are published to stimulate discussion on a broad range of issues on which the OECD works.

Comments on Working Papers are welcomed, and may be sent to the Economics Department, OECD, 2 rue André-Pascal, 75775 Paris Cedex 16, France, or by e-mail to eco.contact@oecd.org.

All Economics Department Working Papers are available at www.oecd.org/eco/workingpapers.

This document and any map included herein are without prejudice to the status of or sovereignty over any territory, to the delimitation of international frontiers and boundaries and to the name of any territory, city or area.

The statistical data for Israel are supplied by and under the responsibility of the relevant Israeli authorities. The use of such data by the OECD is without prejudice to the status of the Golan Heights, East Jerusalem and Israeli settlements in the West Bank under the terms of international law.

Latvia was not an OECD Member at the time of preparation of this publication. Accordingly, Latvia does not appear in the list of OECD Members and is not included in the zone aggregates.

\section{(C) OECD (2016)}

You can copy, download or print OECD content for your own use, and you can include excerpts from OECD publications, databases and multimedia products in your own documents, presentations, blogs, websites and teaching materials, provided that suitable acknowledgment of OECD as source and copyright owner is given. All requests for commercial use and translation rights should be submitted to rights@oecd.org 


\section{ABSTRACT/RESUMÉ}

\section{A bird-eye view of Costa Rica's transport infrastructure}

Costa Rica's transport infrastructure sector has long suffered from insufficient and ineffective investment and maintenance spending, resulting in a congested and poor-quality transport network. Public spending has been below the OECD average and private sector participation is limited. The road network is extensive but of poor quality, railways are in disrepair and only slowly being reactivated after having been shut down in the 1990s, seaports quality and capacity are deficient. Internal transportation overly relies on private road vehicles as the public transport system, especially railways, is inadequate. As a result, the transport sector is the major source of greenhouse emissions. Major challenges hindering the sector performance are: excessive institutional fragmentation, which reduces transparency and accountability of public sector agencies, poor strategic planning, which results in haphazard infrastructure development and poor intermodal connections, aversion to private sector participation and absence of an infrastructureproject pipeline, which discourage private investment, poor project preparation and slow project execution due to no cost benefit analyses, unclear project selection criteria and insufficient stakeholder engagement.

This working paper relates to the 2016 OECD Economic Survey of Costa Rica (www.oecd.org/eco/surveys/economic-survey-costa-rica.htm).

JEL Classification: O18; H54; L91; L98; R28; R40; Q58.

Keywords: transport, infrastructure, concessions, PPPs, roads, airports, seaports, investment, economic development, strategic planning.

\section{Une vue globale de l'infrastructure de transport du Costa Rica}

Le secteur des infrastructures de transport du Costa Rica a longtemps souffert des insuffisantes et inefficaces dépenses d'investissement et de maintenance, qui ont déterminé un réseau de transport congestionné et de mauvaise qualité. Les dépenses publiques ont été en dessous de la moyenne de l'OCDE et la participation du secteur privé est limitée. Le réseau routier est vaste, mais de mauvaise qualité, les chemins de fer sont en mauvais état et sont en train d'être lentement réactivé, après avoir été arrêté dans les années 1990, la qualité et capacité des ports maritimes sont insuffisant. Le transport interne repose excessivement sur les véhicules routiers privés puisque le système de transport public, en particulier les chemins de fer, est peu développé. Par conséquent, le secteur des transports est la principale source des émissions à effet de serre. Les défis majeurs qui entravent la performance du secteur sont: la excessive fragmentation institutionnelle, ce qui réduit la transparence et la responsabilité des organismes publics, une mauvaise planification stratégique, qui se traduit par un développement désordonné des infrastructures et des liaisons intermodales insuffisantes, l'aversion à la participation du secteur privé et l'absence d'une liste des projets d'infrastructure, qui découragent l'investissement privé, la faible qualité de la préparation des projets et leur exécutions lent en raison de la manque d'analyses coûts avantages, des critères flous pour la sélection des projets et engagement des parties prenantes insuffisantes.

Ce Document de travail se rapporte à l'Étude économique de l'OCDE de Costa Rica 2016 (www.oecd.org/fr/eco/etudes/etude-economique-costa-rica.htm).

Classification JEL: O18; H54; L91; L98; R28; R40; Q58.

Mots clés: transports, infrastructures, concessions, PPPs, routes, aéroports, ports maritimes, investissements, développement économique. 


\section{TABLE OF CONTENTS}

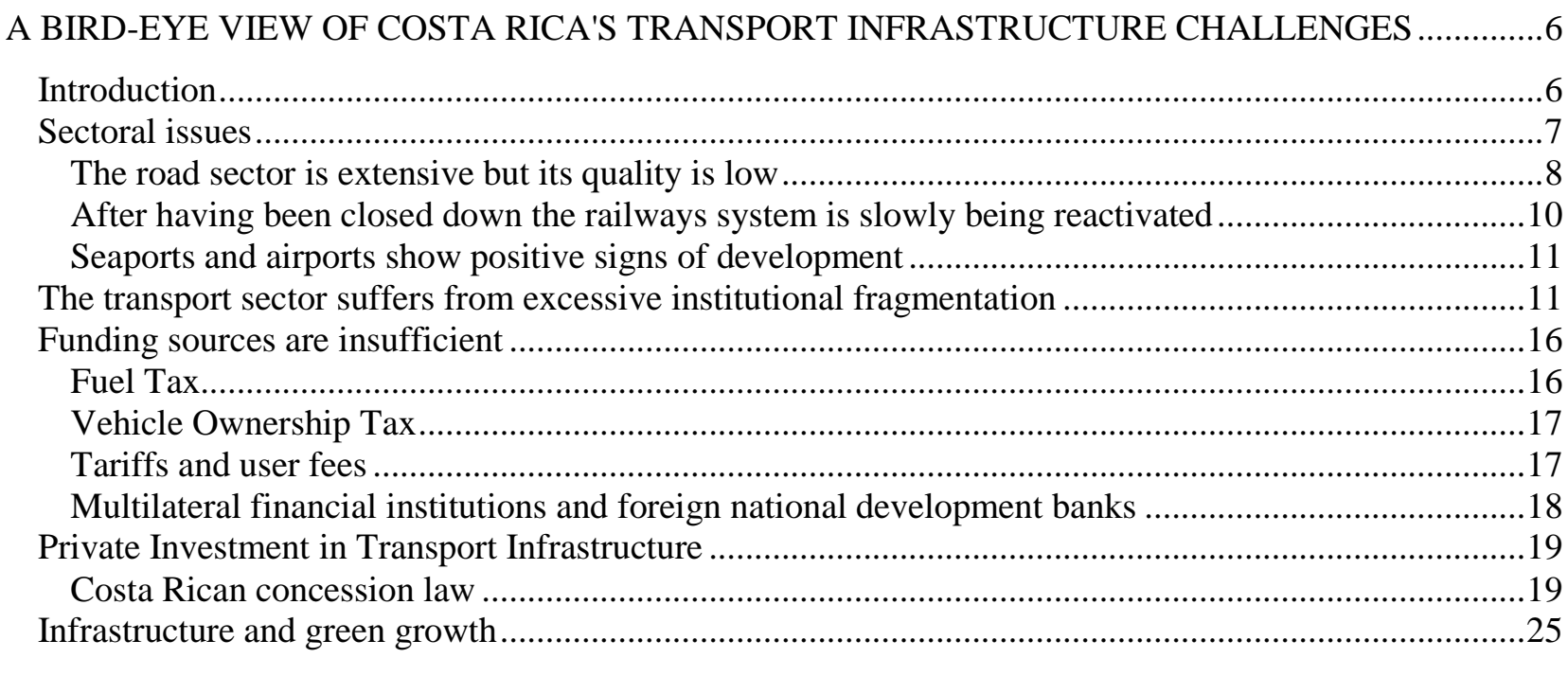

\section{Tables}

1. Costa Rica's road network by jurisdiction and type of surface …......................................................

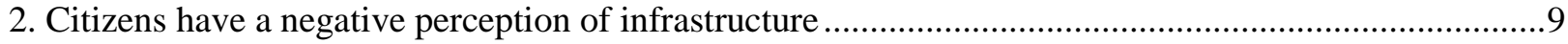

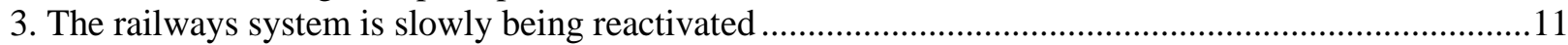

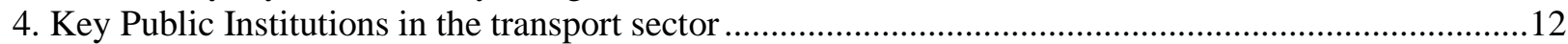

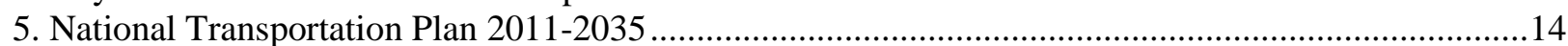

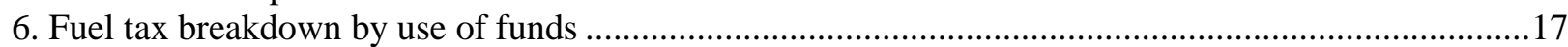

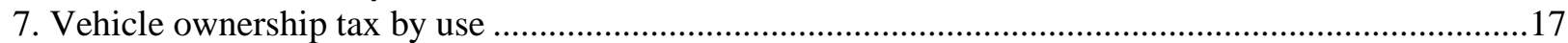

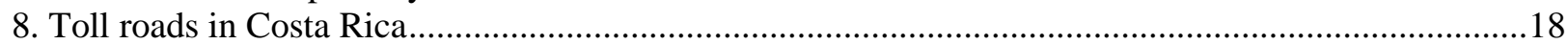

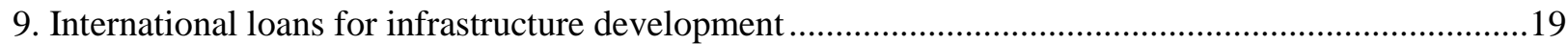

10. Key elements of Costa Rica's PPP and concession framework ......................................................20

11. Transport infrastructure projects involving private participation during the past 2 decades ..............21

12. OECD Principles for Private Sector Participation in Infrastructure and Costa Rica's practices ..........23

13. INCOFER Rapid Train System Project for San Jose great metropolitan area....................................26 


\section{Figures}

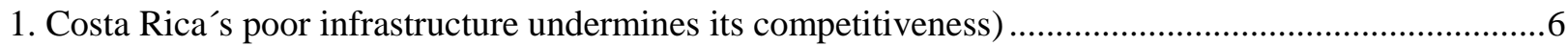

2. Transport infrastructure spending has been below OECD average .................................................

3. There is scope to improve the quality of transport infrastructure …..................................................

4. Only 5\% of national paved roads are in good functional conditions ..................................................10

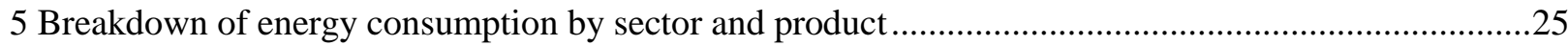

\section{Boxes}

Box 1. San Jose-San Ramon project 


\section{A bird-eye view of Costa Rica's transport infrastructure challenges By Mauro Pisu and Federico Villalobos ${ }^{1}$}

\section{Introduction}

Better transport infrastructure can contribute to higher productivity through various channels. First transport infrastructure can boost the productivity of private inputs because of complementarities with labour and the private capital stock. For instance, improved transport links widens employment opportunities, resulting in a more efficient allocation of labour. Second, the higher productivity of the private capital stock can result in higher private investment (Agénor and Moreno-Dodson, 2006). Third, better transport infrastructure can support more environmentally sustainable growth and mobility patterns. In addition, better integrating physical transport infrastructure plans with land-use and social policies can raise well-being and social welfare, by reducing commuting times and contributing to green and inclusive growth (OECD, 2014b). People with longer commuting time report systematically lower subjective wellbeing (Stutzer and Frey, 2008).

Notwithstanding its fast economic and inclusive development over the past 30 years and its commitment to a green growth path, Costa Rica still suffers from deficient transport infrastructure. Poor transport infrastructure is one of the main obstacle to faster economic growth and higher competiveness (OECD, 2016; WEF, 2015). Survey data on the perceived quality of infrastructure rank Costa Rica $105^{\text {th }}$ worldwide (WEF, 2015) (Figure 1).

Figure 1. Costa Rica's poor infrastructure undermines its competitiveness

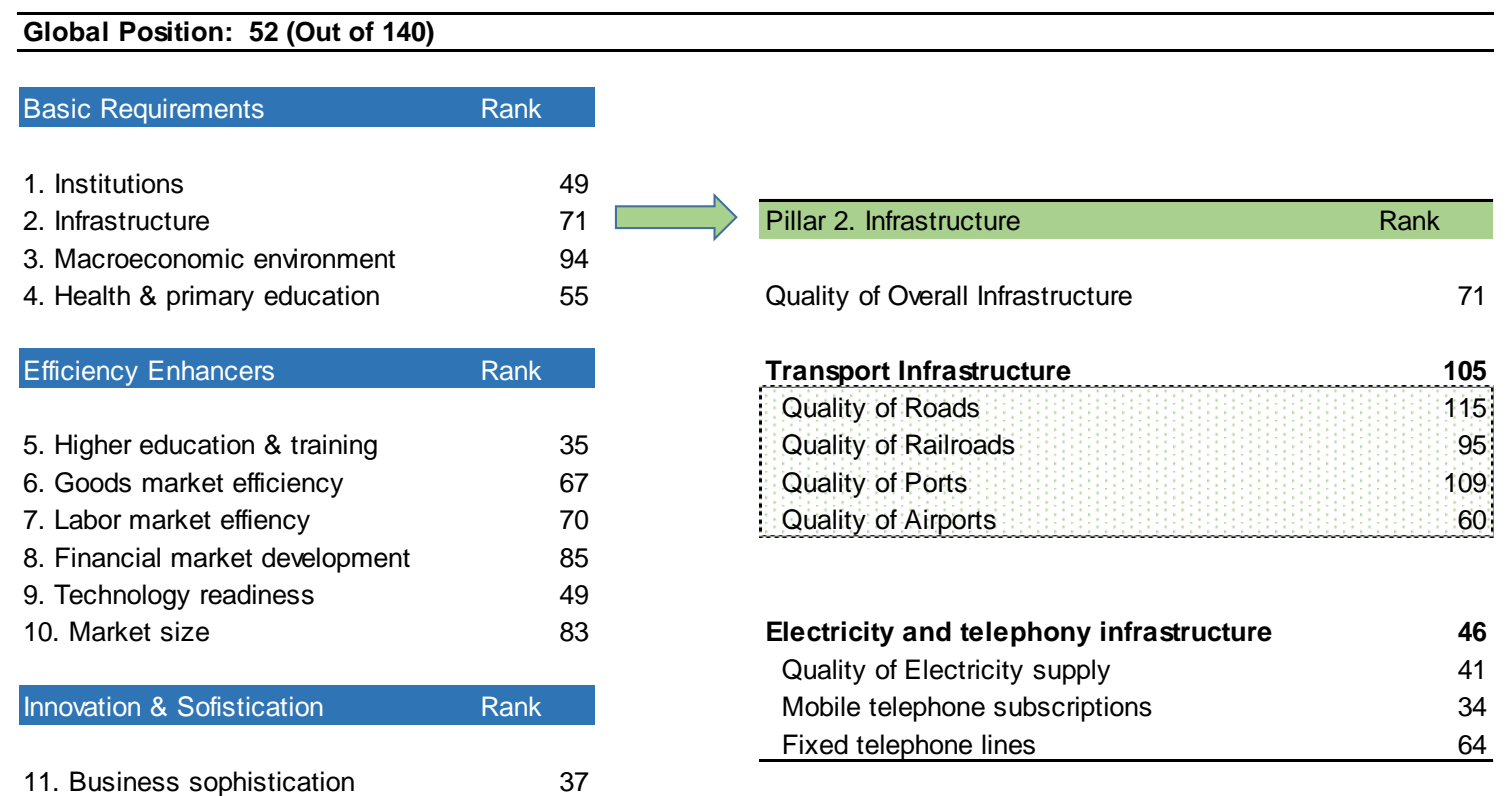

12. Innovation $\quad 39$

Source: WEF (2015).

1. Mauro Pisu (Mauro.PISU@oecd.org) is Senior Economist in the OECD Economics Department. Federico Villalobos (federico.villalobos@gmail.com) is an Economist specialized in infrastructure. The authors would like to thank OECD colleagues: Robert Ford and Patrick Lenain, Economics Department, Ian Hawkesworth, Public Governance and Territorial Development Directorate, Ryan Parmenter, Environment Directorate, Adolfo Rodriguez-Vargas (Costa Rica) for valuable discussions and feedback on earlier drafts. Special thanks to Mabel Gabriel for statistical support and Raquel Paramo for editorial assistance. 
The quality of infrastructure has suffered from decades of insufficient and ineffective spending. From 2002 to 2013, transport infrastructure spending averaged 0.8\% of GDP less than the OECD average (Figure 2). In addition, spending has been ineffective because of the lack of an overall transport infrastructure strategy, policy and regulatory uncertainty stemming from excessive institutional fragmentation resulting in nebulous policy directions, unclear project prioritization, limited execution capacity and resistance to unlock private-sector expertise. The less developed a country is the larger the effect of transport (and non-transport) infrastructure on growth (Estache and Garsous, 2012). Costa Rica as upper middle-income country is at stage of development where better transport infrastructure can still have sizeable effect on economic growth - through large network externalities it will generate by connecting markets, businesses and firms - but at the same time the country needs not to overlook the challenges of improving the environmental impact and safety of new and existing transport infrastructure.

Figure 2. Transport infrastructure spending has been below OECD average

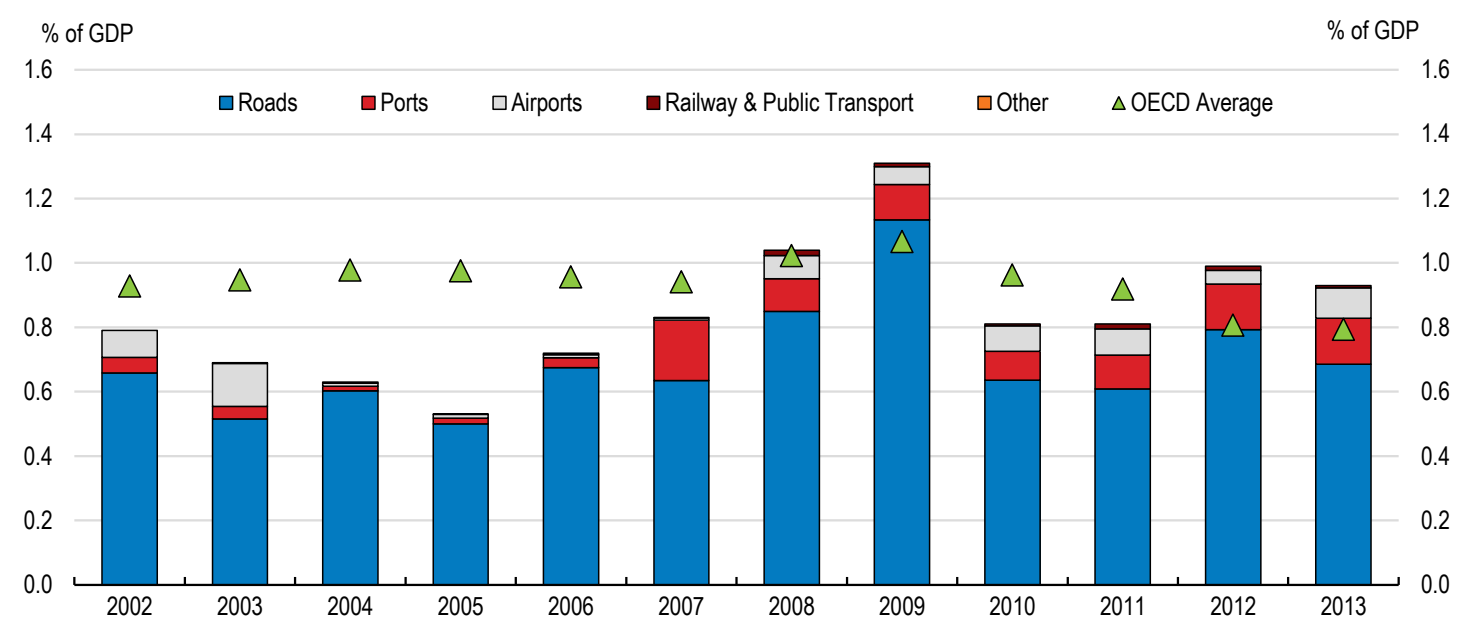

Note: Data for Chile and Israel is not available. OECD is an un-weighted average.

Source: OECD calculations based on based on MOPT (2014, 2011), ECLAC (2014) and OECD Transport Infrastructure Investment and Maintenance Spending database.

The government is aware of the transport infrastructure spending shortfall and the National Transport Plan 2011-2035 (MOPT, 2011) calls for annual infrastructure spending of about 3.7\% of GDP to 2035 (2.45\% of GDP between 2011-2018 and 4\% between 2019-2035). According to the Plan, two thirds of the estimated spending needs should be financed by the public budget with the remaining part coming from the private sector. To be effective and improve the quality of transport infrastructure, the needed increase in infrastructure spending will have to be accompanied by a clear transport infrastructure strategy, lower policy and regulatory uncertainty, faster project execution and an improved framework to attract private participation.

\section{Sectoral issues}

Assessing the quality and quantity of infrastructure is notoriously difficult, as there are no comprehensive internationally comparable data based on objective criteria (Pisu et al., 2012). However survey data on the perceived quality of infrastructure suggest that Costa Rica faces severe problems for roads, ports and railroads while airports perform better (Figure 3). Worldwide, Coat Rica ranks $115^{\text {th }}$ for quality of roads, $95^{\text {th }}$ for railroads, $109^{\text {th }}$ for ports and $60^{\text {th }}$ for airports $\left(60^{\text {th }}\right)(\mathrm{WEF}, 2015)$. 
Figure 3. There is scope to improve the quality of transport infrastructure

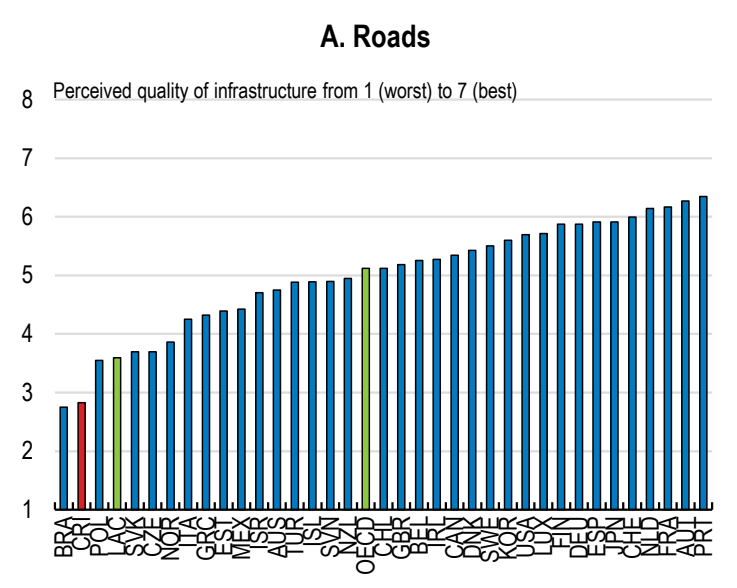

C. Railroad

7 Perceived quality of infrastructure from 1 (worst) to 7 (best)

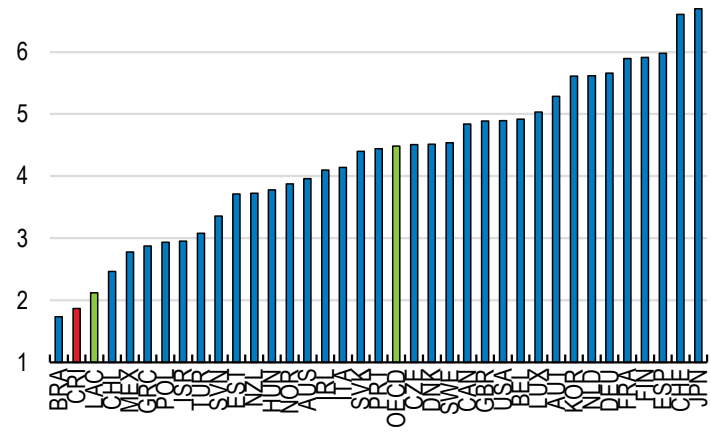

B. Ports

8 Perceived quality of infrastructure from 1 (worst) to 7 (best)

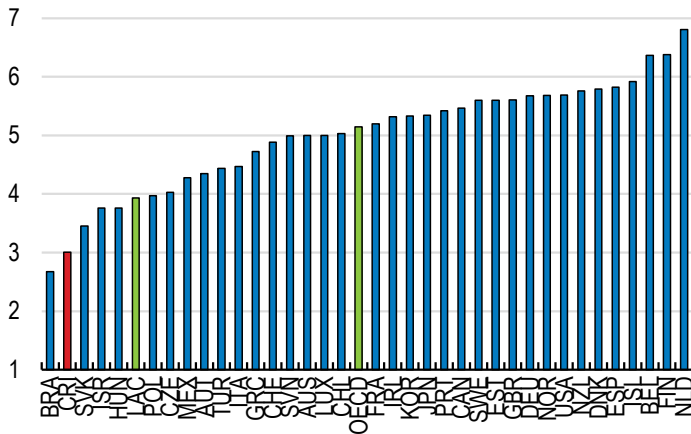

D. Air transport

8 Perceived quality of infrastructure from 1 (worst) to 7 (best)

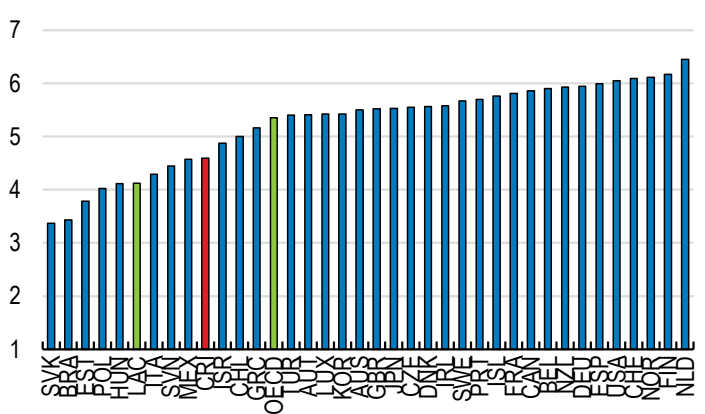

Note: Figures refer to the following question: How would you assess general infrastructure in your country (from 1 = extremely underdeveloped - among the worst in the world to 7 = extensive and efficient - among the best in the world). The OECD and Latin America \& Caribbean (LAC) aggregate are calculated as an unweighted average.

Source: World Economic Forum (2014), The Global Competitiveness Report 2014-2015, Geneva.

\section{The road sector is extensive but its quality is low}

The road network is well developed and is nearly $43000 \mathrm{~km}$ long (Table 1). Nearly $20 \%$ (8000 km) of the road network are part of the national road network which is maintained by the National Roads Council (CONAVI). The remaining roads are part of the cantonal road network, maintained by municipalities. Compared to peers, Costa Rican road network is extensive as it counts $84 \mathrm{~km}$ per 100 square $\mathrm{km}$ of land, four times the average for Latin America (World Bank, 2012). However, road quality is low; according to a national inventory $62 \%$ of roads show deficient or very deficient conditions, $33 \%$ are in regular condition, 5\% in good condition and none is in very good condition. Most bridges are at structural risk of collapsing due to natural deterioration (LANAMMEUCR, 2015) (Figure 4). Regarding bridges and sidewalks, quality perceptions by citizens are especially low (Table 2). Poor road conditions are mainly driven by many cumulative years of postponed maintenance. Most of the road infrastructure was developed before the economic crisis of the 1980s, after which, fiscal adjustments forced budget cuts that disproportionally fell on infrastructure (Vasssallo, 2015). 
Table 1. Costa Rica's road network by jurisdiction and type of surface

2014

\begin{tabular}{cccc}
\hline Road Network & National (km) & Municipal (km) & Total (km) \\
\hline Paved & 5,269 & 6,547 & 11,816 \\
Graved or Dirt & 2,512 & 28,540 & 31,052 \\
Total & 7,781 & 35,087 & 42,868 \\
\hline
\end{tabular}

Source: MOPT (2014) and LANAMMEUCR (2015).

Table 2. Citizens have a negative perception of infrastructure.

2015

\begin{tabular}{cccc}
\hline $\begin{array}{c}\text { Condition of } \\
\text { Infrastructure }\end{array}$ & Roads & Bridges & Sidewalks \\
\hline Very Bad & 37.0 & 28.1 & 37.9 \\
Bad & 30.9 & 32.6 & 28.6 \\
Regular & 21.3 & 28.2 & 21.9 \\
Good & 8.6 & 8.9 & 9.3 \\
Excellent & 1.6 & 0.7 & 0.9 \\
NR & 0.5 & 1.5 & 1.3 \\
Total & 100.0 & 100.0 & 100.0 \\
\hline
\end{tabular}

Source: LANAMMEUCR (2015).

Despite the low quality of the road network, the number of vehicles in circulation rose by $68 \%$ from 2003 to 2014 (MOPT, 2014) contributing to increased congestion. Because the railways system is underdeveloped there are no realistic alternative to cars and buses. Also in cities, there are no exclusive bike lanes or wide sidewalks and car owners find public transportation unappealing.

One of the main priorities of the National Transport Plan 2011-2035 is the rehabilitation, maintenance and expansion of the road network. The maintenance programme appears to be working well as between 2011 and 2014 it has reached and surpassed its goals (CONAVI, 2015). Concerning, new major projects, the past 10 years were limited to Route 27 "San José Caldera" and Route 34 "Costanera Sur". Should the underinvestment continue, it is likely that spending needs will be rise above current estimates. 
Figure 4 . Only $5 \%$ of national paved roads are in good functional conditions.

2014-2015.

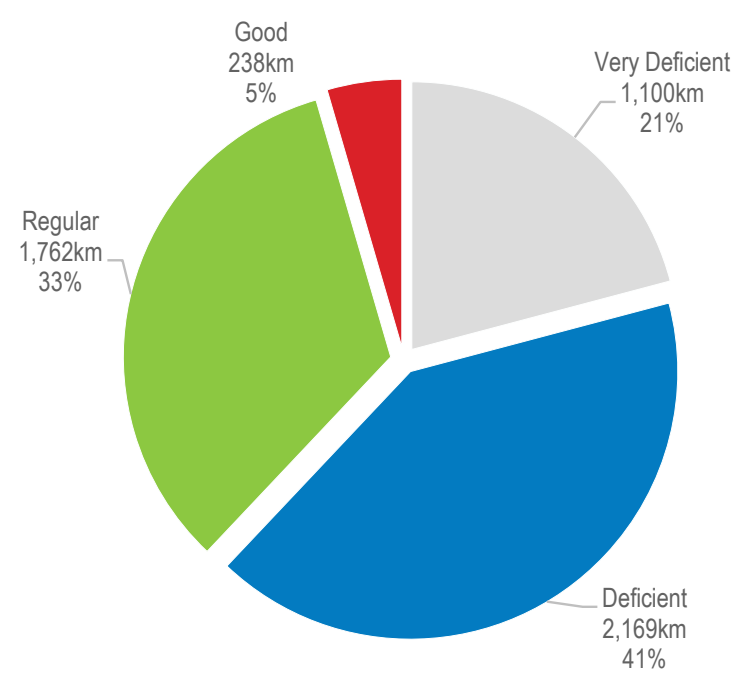

Source: LANAMMEUCR (2015).

\section{After having been closed down the railways system is slowly being reactivated}

In the second half of the 1990s the government decided to close the railways system down. The decision was reversed some years later (MOPT, 2011) and railways tracks are being rehabilitated and routes reopened. Since 2005 limited urban and interurban railways services have started again in the metropolitan area of San Jose (Table 3). However, improvements in railways services have been uneven as routes were reopened without performing demand analyses, there are no procedures to collect and compute demand statistics, no clear standards to ensure quality of services and no modern information and communication technologies (CGR, 2014).

A long standing plan of developing a sorely needed mass rapid transit system in the Great Metropolitan Area (GAM) of San Jose - where half of the population lives - has made no actual progress. The latest proposal would cost USD 1400 million and be completed by October 2022 (INCOFER, 2014). About $75 \%$ of all passenger traffic in the GAM relies on public transport, mostly buses as the role of railways is marginal (MOPT, 2011). The mass rapid transit system and, more generally, the improvement of the railway, are paramount to reduce road transport congestion and pollution. A metro-regional approach would contribute to faster progress in this area. A metro-regional approach involves strengthening oversight, coordination and guidance of municipalities' land-use planning and land development decisions. Metropolitan areas across the OECD pursue a range of governance approaches, which could be useful to Costa Rica. They range from purely informal associations of local governments to full sub-national governments and generally fall into four categories: 1) informal/soft coordination; 2) inter-municipal authorities; 3) supra-municipal authorities; and 4) special status of "metropolitan cities" (Ahrend and Schumann (2014), OECD, 2014b). While no one-fits-all model exists, evidence suggests that where metropolitan co-ordination has occurred it has often contributed to better urban policies. Integrating the governance of transport and the governance of spatial planning also helps prevent costly consequences of urban sprawl and promotes a more balanced urban development (OECD, 2015a). 
Table 3. The railways system is slowly being reactivated Routes in the Great Metropolitan Area of San Jose; 2014

\begin{tabular}{l|lll|}
\hline \multicolumn{1}{|c|}{ Locations connected } & Km & \multicolumn{1}{c|}{ Started operations } \\
Pavas-San Pedro & 8.0 & 2005 \\
Heredia-San José & 9.6 & 2009 \\
San Pedro-Curridabat & 6.8 & 2010 \\
Belén-San José & 14.4 & 2011 \\
Cartago-San José & 20.6 & 2013 \\
Total & 59.4 & NA \\
\hline
\end{tabular}

Source: CGR (2014).

\section{Seaports and airports show positive signs of development}

Positive steps have recently been taken to ameliorate seaports and airports. In 2015, the Grain Terminal of Caldera Port was inaugurated and the construction phase of the Moin Container Terminal was started in the Caribbean coast. Both projects were executed through concession schemes. In airports, the private-sector participation has also been used. The Juan Santamaria International Airport (USD 138 million) was modernized and expanded, and the Passenger Terminal of the Liberia International Airport (USD 35 million) was inaugurated.

\section{The transport sector suffers from excessive institutional fragmentation}

The transport infrastructure planning and decision making processes are highly fragmented among different ministries and government agencies (Table 4). This may be one of the reasons why public infrastructure projects are often the result of individual institutional efforts, do not follow common approaches and suffer from inadequate preparation (CGR, 2012). For instance, the Ministry of Planning publishes guidelines for public infrastructure projects, but these are only optional as there are not enforcement mechanisms.

The Ministry of Public Works (MOPT) is the institution responsible for transport planning and policy design. MOPT has historically been in charge also of project execution, building, maintaining and operating transport infrastructure but the creation in the late 1990s of independent and semi-independent agencies with ample administrative freedom and decision powers over these issues has limited its role to planning and policy design. The agencies that were created are: CONAVI, with responsibilities for extending and maintaining the national road network; $\mathrm{CNC}$, which promotes and manages concession projects -across the whole infrastructure sector; and CTP, responsible for policies relating to public road transport (i.e. taxis, buses and coaches). Other important government bodies having crucial role in transport infrastructure are: the National Railways Institute (INCOFER), which manages and operates the railways system; the Costa Rican Institute for Pacific Ports (INCOP) and the Port Management Board of the Atlantic Coast Development (JAPDEVA), which are port authorities of the Pacific and Caribbean seaports, respectively; the Technical Civil Aviation Council (CETAC) and the Road Safety Council (COSEVI) formulate policies for civil aviation and road safety. Finally, other public institutions have horizontal roles. These include the Regulatory Authority of Public Services (ARESEP), with responsibilities for fixing tariffs for buses, taxis, trains and ports, and the National Environmental Office (SETENA) - within the Ministry of Environment and Energy - assesses infrastructure projects' environmental impacts. Looking at related institutions, the Ministry of Planning has the mandate to develop and update the national development plan (covering four years), which covers also transport, and to ensure that the investment projects are aligned with this. Finally, the Ministry of Finance plays a marginal role in the transport infrastructure as it does not actively participate in setting policy directions, project preparation, evaluation and prioritization. Its role is mainly limited to authorizing tax exemptions to incentivize private-sector participation. 
Table 4. Key Public Institutions in the transport sector

\begin{tabular}{|c|c|c|c|c|}
\hline Institution & $\begin{array}{l}\text { Type (budget } \\
\text { allocation) }\end{array}$ & $\begin{array}{l}\text { Year of } \\
\text { creation }\end{array}$ & $\begin{array}{c}\text { Governing } \\
\text { Law }\end{array}$ & Responsibilities \\
\hline \multicolumn{5}{|c|}{ Institutions with specific responsibility for the transport infrastructure sector } \\
\hline $\begin{array}{l}\text { Ministry of Public Works } \\
\text { (MOPT) }\end{array}$ & $\begin{array}{l}\text { Ministry (Central } \\
\text { government) }\end{array}$ & 1963 & No.3155 & $\begin{array}{l}\text { Planning agency; issue the } \\
\text { National Transport Plan }\end{array}$ \\
\hline $\begin{array}{l}\text { Technical Civil Aviation } \\
\text { Council (CTAC) }\end{array}$ & $\begin{array}{c}\text { De-concentrated } \\
\text { agency under MOPT }\end{array}$ & 1973 & No.5150 & $\begin{array}{l}\text { Issuing regulations on air } \\
\text { transport and promoting } \\
\text { development of airport } \\
\text { infrastructure }\end{array}$ \\
\hline $\begin{array}{l}\text { Road Safety Council } \\
\text { (COSEVI) }\end{array}$ & $\begin{array}{c}\text { De-concentrated } \\
\text { agency under MOPT }\end{array}$ & 1979 & No.6324 & $\begin{array}{l}\text { Issuing regulations to } \\
\text { increase the safety of the } \\
\text { road transports }\end{array}$ \\
\hline $\begin{array}{l}\text { National Concessions } \\
\text { Council (CNC) }\end{array}$ & $\begin{array}{c}\text { De-concentrated } \\
\text { agency under MOPT }\end{array}$ & 1998 & No.7762 & $\begin{array}{l}\text { Promoting private } \\
\text { participation through } \\
\text { concessions and PPPs }\end{array}$ \\
\hline $\begin{array}{l}\text { National Road Council } \\
\text { (CONAVI) }\end{array}$ & $\begin{array}{c}\text { De-concentrated } \\
\text { agency under MOPT }\end{array}$ & 1998 & No.7798 & $\begin{array}{l}\text { Building and maintaining the } \\
\text { road network }\end{array}$ \\
\hline $\begin{array}{l}\text { Public Transportation } \\
\text { Council (CTP) }\end{array}$ & $\begin{array}{l}\text { De-concentrated } \\
\text { agency under MOPT }\end{array}$ & 1999 & No.7969 & $\begin{array}{l}\text { Issuing regulations relating } \\
\text { to public road transport (i.e. } \\
\text { taxis, buses and coaches) }\end{array}$ \\
\hline $\begin{array}{l}\text { Costa Rican Institute of } \\
\text { Pacific Ports (INCOP) }\end{array}$ & $\begin{array}{l}\text { Non-financial pubic } \\
\text { company }\end{array}$ & 1953 & No.1721 & $\begin{array}{l}\text { Port authorities for Pacific } \\
\text { ports }\end{array}$ \\
\hline $\begin{array}{l}\text { Port Management Board of } \\
\text { the Atlantic Coast } \\
\text { Development (JAPDEVA) }\end{array}$ & $\begin{array}{l}\text { Non-financial pubic } \\
\text { company }\end{array}$ & 1963 & No.3091 & $\begin{array}{l}\text { Port authorities for Atlantic } \\
\text { ports }\end{array}$ \\
\hline $\begin{array}{l}\text { National Railway Institute } \\
\text { (INCOFER) }\end{array}$ & $\begin{array}{l}\text { Non-financial pubic } \\
\text { company }\end{array}$ & 1985 & No.7001 & $\begin{array}{l}\text { Managing the railways } \\
\text { system (stations, tracks and } \\
\text { rolling stock) }\end{array}$ \\
\hline \multicolumn{5}{|c|}{ Institutions with an horizontal role } \\
\hline $\begin{array}{l}\text { Regulatory Authority of } \\
\text { Public Services (ARESEP) }\end{array}$ & $\begin{array}{l}\text { De-centralised } \\
\text { institution }\end{array}$ & 1928 & No.7593 & $\begin{array}{l}\text { Setting tariffs for buses, } \\
\text { taxis, trains and ports }\end{array}$ \\
\hline $\begin{array}{l}\text { Ministry of Planning } \\
\text { (MIDEPLAN) }\end{array}$ & Ministry & 1974 & No. 5525 & $\begin{array}{l}\text { Coordinating agency and } \\
\text { issuing the National } \\
\text { Development Plan }\end{array}$ \\
\hline Ministry of Finance & Ministry & 1885 & $\begin{array}{l}\text { Decree } \\
\text { No. } 55\end{array}$ & $\begin{array}{c}\text { Authorizing tax exemptions } \\
\text { to incentivize private-sector } \\
\text { participation }\end{array}$ \\
\hline $\begin{array}{l}\text { Ministry of Environment } \\
\text { and Energy (MINAE) }\end{array}$ & Ministry & 1990 & No.7152 & \\
\hline $\begin{array}{l}\text { National Environmental } \\
\text { Office (SETENA) }\end{array}$ & $\begin{array}{c}\text { De-concentrated } \\
\text { agency under MINAE }\end{array}$ & 1995 & No. 7554 & $\begin{array}{l}\text { Issuing environmental } \\
\text { permits }\end{array}$ \\
\hline
\end{tabular}

Source: Elaboration based on MIDEPLAN (2007) and Ministry of Finance (2014)

The numerous public agencies and bodies involved in transport infrastructure contribute to excessive policy fragmentation and uncertainty. This impinges negatively on the overall policy coherence of the sector and contributes to delay projects execution. An analysis of 15 transport infrastructure projects found delays between three and ten years from the time the contractor is selected to the start the construction (CGR, 2012). Some of the projects included in the CGR's study have accumulated over 20 years of delay since the project inception (e.g. San Jose-San Ramon project). Projects financed with funds from multilateral institutions are not exception, resulting in large amount of available but unspent funds. For instance, credit contract for the First Road Infrastructure Program (PIV 1) with the Inter-American Development Bank (IADB) was signed in 2009, however almost 6 years later PIV 1 has only a 69\% of financial progress (Table 9). 
In 2008, the Comptroller General (CGR) recommended to the central government the development of a national plan to set a clear path for mid- and long-term investments. CGR's advice follows international best practices, according to which national policy frameworks must set down how strategic infrastructure is to be planned, evaluated, developed and financed, as well as provide a solid basis for communication with stakeholders and the public (OECD, 2011). Following this suggestion the government of Costa Rica established the National Transport Plan 2011-2035 (NTP) as an official public policy under Executive Decree No. 37738-MOPT of May 2013 (Table 5). The NTP is a first step in the right direction but it primarily serves as guidance for institutions involved in transport infrastructure and it lacks legal enforcement mechanisms.

A simpler institutional framework would also contribute to a more effective transport infrastructure strategy. For instance, different agencies could be merged; at the minimum the government could better articulate the policy mandate of the different ministries and agencies and clearly identify lead agencies. To overcome institutional fragmentation, some OECD countries have created dedicated agencies to develop long-term strategies and plans, such as Australia (Infrastructure Australia) and the United Kingdom (Infrastructure UK), with good results. Strategic planning could help link transport infrastructure objectives with wider socio-economic and environmental benefits, making it less likely that public transport infrastructure spending be cut because of short-term budget and political pressures. Long term strategic planning should be complemented with a clear and reliable project pipeline, listing the investment projects the government intends to build, with either public or private funds, and consistent with the long-term strategic goals. 


\section{Table 5. National Transportation Plan 2011-2035}

\begin{tabular}{|c|c|c|c|}
\hline Sector & State of Infrastructure & Main Operative Objectives 2011-2018 & Main Strategic Objective 2019-2035 \\
\hline \multirow[t]{2}{*}{ Road Network } & $\begin{array}{l}\text { - Historical lack of adequate maintenance across the } 42,868 \mathrm{~km} \text { network. } \\
\text { High density considering the Costa Rica's } 51,000 \mathrm{~km}^{2} \text { of Costa Rican } \\
\text { territory. } \\
\text { - Limited capacity and functionality of the road network. } \\
\text { - MOPT has insufficient endowment of human, financial and technical } \\
\text { resources to manage the complete project life cycle (planning, } \\
\text { procurement, construction, operation and maintenance). } \\
\text { - Average Annual Investment 2002-2013: } 0.69 \% \text { of GDP }\end{array}$ & $\begin{array}{l}\text { - Enactment of technical guidelines to develop road } \\
\text { infrastructure projects through their entire life cycles. } \\
\text { - Execution of maintenance and rehabilitation of existing road } \\
\text { stock. } \\
\text { - Preparation, design and bidding of projects to expand the } \\
\text { capacity of the Strategic Highway Network (SHN). } \\
\text { - Preparation, design and procurement of projects to expand the } \\
\text { capacity of the Local Road Network (LRN).. }\end{array}$ & $\begin{array}{l}\text { Completion of the expansion of the SHN. } \\
\text { Completion of strategic arterial roads and highways in urban } \\
\text { and metropolitan areas. }\end{array}$ \\
\hline & Annual Investment Requirements & $1.76 \%$ of GDP & $3.10 \%$ of GDP \\
\hline \multirow[t]{2}{*}{ Seaports } & $\begin{array}{l}\text { - International traffic seaport network comprises of } 5 \text { facilities in the } \\
\text { Pacific coast (Caldera, Puntarenas, Fertica, Punta Morales and Golfito) } \\
\text { and } 2 \text { facilities in the Caribbean (Limon and Moin). } \\
\text { - Limited capacity and functionality of the seaport network. } \\
\text { - The seaport system is in dire need of a major expansion (mainly in the } \\
\text { Caribbean coast) to meet increasing services demand. Approximately } \\
80 \% \text { of total international commerce is mobilized through seaports. } \\
\text { - Average Annual Investment 2002-2013: } 0.09 \% \text { of GDP }\end{array}$ & $\begin{array}{l}\text { - Execute maintenance and rehabilitation of existing seaport } \\
\text { facilities. } \\
\text { - As a first priority, construction of phase } 1 \text { of the expansion of } \\
\text { the Moin Port (project started construction in } 2015 \text { under a } \\
\text { concession scheme). } \\
\text { - Procurement process of a cruise terminal in Limon. } \\
\text { - Development of a grain terminal in Caldera and expansion of } \\
\text { terminals in the Pacific coast.(Grain terminal is now } \\
\text { operational under concession). }\end{array}$ & $\begin{array}{l}\text { Completion of the Moin Port expansion. } \\
\text { Completion of cruise terminal in Limon and port expansions in } \\
\text { the Pacific coast. }\end{array}$ \\
\hline & Annual Investment Requirements & $0.28 \%$ of GDP & $0.15 \%$ of GDP \\
\hline \multirow[t]{2}{*}{ Railways } & $\begin{array}{l}\text { - The country has a } 212 \mathrm{~km} \text { network, with one line to the Pacific and one } \\
\text { line to the Caribbean. Urban service has been timidly reactivated since } \\
2005 \text {. Cargo service is limited to bananas and iron in the Caribbean. } \\
\text { - Railway infrastructure is poor, after decades of abandonment. } \\
\text { - Urban rail service has been timidly reactivated. } \\
\text { - Average Annual Investment 2002-2013: } 0.01 \% \text { of GDP }\end{array}$ & $\begin{array}{l}\text { - Execution of maintenance and rehabilitation of existing road } \\
\text { stock. } \\
\text { Preparation, design and bidding of projects of new stations } \\
\text { and railway tracks. }\end{array}$ & $\begin{array}{l}\text { - Completion of new railway system. } \\
\text { - Systematization of maintenance and operation activities. }\end{array}$ \\
\hline & Annual Investment Requirements & $0.14 \%$ of GDP & $0.36 \%$ of GDP \\
\hline
\end{tabular}


ECO/WKP(2016)47

\begin{tabular}{|c|c|c|c|}
\hline Sector & State of Infrastructure & Main Operative Objectives 2011-2018 & Main Strategic Objective 2019-2035 \\
\hline \multirow[t]{2}{*}{ Airports } & $\begin{array}{l}\text { - Most of the population (97\%) is less than } 50 \mathrm{~km} \text { away from airport } \\
\text { facilities (local or international) with regular service. } \\
\text { - There are two major international airports, Juan Santamaria (SJO) in } \\
\text { Alajuela and Daniel Oduber (LIB) in Liberia. Both airports operate } \\
\text { under a public private partnership (PPP). LIB's PPP is limited to the } \\
\text { passenger terminal. } \\
\text { - Tobias Bolaños is the third International airport, serving as the base for } \\
\text { private charters, training and domestic and some regional tourism } \\
\text { operations (Morales and Pratt, 2012). } \\
\text { - Costa Rica has adequate airport infrastructure to meet short and mid- } \\
\text { term requirements. However, its main international airport (SJO) is } \\
\text { close to reaching maximum capacity. } \\
\text { - Average Annual Investment 2002-2013: } 0.06 \% \text { of GDP }\end{array}$ & $\begin{array}{l}\text { - Preparation, design and public bidding of a new international } \\
\text { airport. New international airport is expected to start } \\
\text { operations in } 2025 \text {. } \\
\text { - Execute expansion and maintenance projects for local } \\
\text { airports. } \\
\text { - Execute expansion and maintenance projects for existing } \\
\text { international airport. }\end{array}$ & $\begin{array}{l}\text { - Completion of new international airport } \\
\text { - Completion of expansion projects of existing airport system. }\end{array}$ \\
\hline & Annual Investment Requirements & $0.10 \%$ of GDP & $0.20 \%$ of GDP \\
\hline \multirow[t]{2}{*}{$\begin{array}{l}\text { Public } \\
\text { Transport }\end{array}$} & $\begin{array}{l}\text { Bus transport system is highly inefficient. } \\
\text { Lack of intermodal infrastructure to connect bus transport with train } \\
\text { services. } \\
\text { Average Annual Investment 2002-2013: NA }\end{array}$ & $\begin{array}{l}\text { - Reorganization of public transport system (mainly buses). } \\
\text { - Preparation, design and public bidding of new infrastructure } \\
\text { for bus transportation and intermodal services. }\end{array}$ & $\begin{array}{l}\text { - Completion of new infrastructure for bus transportation and } \\
\text { intermodal services. } \\
\text { - Systematization of maintenance and operation activities. }\end{array}$ \\
\hline & Annual Investment Requirements & $0.09 \%$ of GDP & $0.15 \%$ of GDP \\
\hline $\begin{array}{l}\text { Institutional } \\
\text { Reforms }\end{array}$ & Annual Investment Requirements & $0.05 \%$ of GDP & $0.02 \%$ of GDP \\
\hline $\begin{array}{l}\text { Logistics \& } \\
\text { Other }\end{array}$ & Annual Investment Requirements & $0.03 \%$ of GDP & $0.02 \%$ of GDP \\
\hline \multicolumn{2}{|c|}{ Total Annual Investment Requirements } & $2.45 \%$ of GDP & $4.00 \%$ of GDP \\
\hline
\end{tabular}

Source: Author's elaboration based on Ministry of Public Works (2011), Ministry of Public Works (2014 and 2011) and ECLAC (2014). 


\section{Funding sources are insufficient}

Costa Rica has traditionally funded public infrastructure via taxes, user fees and loans from multilateral institutions but funds have persistently fallen short of spending needs. The amount of funds from multilateral institutions devoted to infrastructure projects is substantial but the current total stock adds up to only $3 \%$ of GDP, equivalent to the investment gap of one year.

The Fuel Tax (FT) and the Vehicle Ownership Tax (VOT) are the main tax-related funding sources for road transport. However, there is a large dissociation between the population's perception of taxes paid and public services provided. Only a small percentage of collected fuel and vehicle ownership taxes is directed towards road construction and maintenance. Further, government-operated toll roads work under tariff schemes that respond to political decisions rather than real project-funding needs.

Regarding airports, main international facilities (Juan Santamaria and Liberia) are funded from the exit tax (tariff of USD29), along with charges to airlines and ancillary revenues from commercial activity. Of note, both airports operate under PPP schemes with the participation of foreign investors. Similarly, ports sustain their operation and investments from user charges, especially those facilities with privatesector financing and operation (Caldera Port and future Moin Container Terminal).The public transportation system also relies on user fees, which are well below cost recovery levels.

\section{Fuel Tax}

Law No. 8114 of "Fiscal Simplification and Efficiency", established a lump-sum tax on all types of fossil fuels in addition to asphalt products. As of July 31, 2015, the fuel tax represented about $36 \%$ of gasoline price/liter and 30\% of diesel price/liter (RECOPE, 2015). This legislation sets that $30 \%$ of the fuel tax must be directed to road infrastructure investment, more specifically: $21.8 \%$ to CONAVI, $7.3 \%$ to municipalities to maintain local roads and $1.0 \%$ to LANAMMEUCR to supervise the quality of the national network.

Although the legislation clearly mandates how tax fuel receipts are to be used, consumers have the expectation that $100 \%$ of the fuel tax is directed to road building and maintenance. This expectation significantly reduces the users' willingness to pay a toll. According to CGR $(2013,2015)$, the fuel tax generates annual fiscal income of about $1.5 \%$ of GDP; however, of this amount, only $0.3 \%$ of GDP is destined to maintaining national routes (central-government managed) and $0.1 \%$ of GDP to maintaining the municipal road network (local-government managed) (Table 6). The lack willingness to pay a toll by the population is a serious obstacle to the development of a toll road network, which could be addressed through better stakeholder engagement. 
Table 6. Fuel tax breakdown by use of funds

\begin{tabular}{lccccccccc} 
& \multicolumn{10}{c}{ \% of GDP } \\
\hline & $\mathbf{2 0 0 9}$ & $\mathbf{2 0 1 0}$ & $\mathbf{2 0 1 1}$ & $\mathbf{2 0 1 2}$ & $\mathbf{2 0 1 3}$ & $\mathbf{2 0 1 4}$ & $\mathbf{2 0 1 5}$ & $\mathbf{2 0 1 6}$ \\
\hline Total (A+B) & $\mathbf{1 . 8 3}$ & $\mathbf{1 . 6 8}$ & $\mathbf{1 . 7 2}$ & $\mathbf{1 . 5 5}$ & $\mathbf{1 . 6 4}$ & $\mathbf{1 . 5 2}$ & $\mathbf{1 . 4 7}$ & $\mathbf{1 . 4 2}$ \\
& & & & & & & & \\
A. Infrastructure & & & & & & & & \\
investment & $\mathbf{0 . 5 2}$ & $\mathbf{0 . 4 7}$ & $\mathbf{0 . 4 9}$ & $\mathbf{0 . 4 4}$ & $\mathbf{0 . 4 6}$ & $\mathbf{0 . 4 3}$ & $\mathbf{0 . 4 1}$ & $\mathbf{0 . 4 0}$ \\
$\quad$ National roads (CONAVI) & 0.37 & 0.34 & 0.35 & 0.32 & 0.34 & 0.31 & 0.30 & 0.29 \\
Municipal roads & 0.12 & 0.11 & 0.12 & 0.11 & 0.11 & 0.10 & 0.10 & 0.10 \\
LANAMMEUCR & 0.02 & 0.02 & 0.02 & 0.01 & 0.02 & 0.01 & 0.01 & 0.01 \\
& & & & & & & & \\
B. Other expenses & $\mathbf{1 . 3 1}$ & $\mathbf{1 . 2 1}$ & $\mathbf{1 . 2 3}$ & $\mathbf{1 . 1 1}$ & $\mathbf{1 . 1 8}$ & $\mathbf{1 . 0 9}$ & $\mathbf{1 . 0 6}$ & $\mathbf{1 . 0 2}$ \\
Current expenses & 1.13 & 1.04 & 1.07 & 0.96 & 1.02 & 0.94 & 0.91 & 0.88 \\
Judiciary (6\%) & 0.11 & 0.10 & 0.10 & 0.09 & 0.10 & 0.09 & 0.09 & 0.09 \\
Red Cross & 0.01 & 0.01 & 0.01 & 0.01 & 0.01 & 0.01 & 0.01 & 0.01 \\
FONAFIFO & 0.06 & 0.06 & 0.06 & 0.05 & 0.05 & 0.05 & 0.05 & 0.05 \\
\hline
\end{tabular}

Source: Author's elaboration based on CGR $(2013,2015)$.

\section{Vehicle Ownership Tax}

Law No. 7088 of "Fiscal Adjustment" established a tiered vehicle ownership tax (1.2\% to 3.5\%) based on vehicles market values. Regarding its mandatory uses, Law No. 7798 indicates that $50 \%$ must be directed to CONAVU for the maintenance and expansion of the national road network. As with the fuel tax, there is an expectation from the general public that $100 \%$ of the proceeds of this tax be used to improve road conditions, but actually less than $50 \%$ is destined to this use (Table 7).

Table 7. Vehicle ownership tax by use

$\%$ of GDP

\begin{tabular}{|c|c|c|c|c|c|c|c|c|}
\hline & 2009 & 2010 & 2011 & 2012 & 2013 & 2014 & 2015 & 2016 \\
\hline Total $(A+B)$ & 0.46 & 0.49 & 0.41 & 0.45 & 0.46 & 0.49 & 0.51 & 0.51 \\
\hline $\begin{array}{ll}\text { A. } & \text { Infrastructure } \\
\text { investment } & \end{array}$ & 0.22 & 0.23 & 0.19 & 0.21 & 0.22 & 0.23 & 0.24 & 0.24 \\
\hline National roads (CONAVI) & 0.22 & 0.23 & 0.19 & 0.21 & 0.22 & 0.23 & 0.24 & 0.24 \\
\hline B. Other expenses & 0.24 & 0.26 & 0.22 & 0.24 & 0.24 & 0.26 & 0.27 & 0.27 \\
\hline General current expenses & 0.22 & 0.23 & 0.19 & 0.21 & 0.22 & 0.23 & 0.24 & 0.24 \\
\hline Judiciary $(6 \%)$ & 0.03 & 0.03 & 0.02 & 0.03 & 0.03 & 0.03 & 0.03 & 0.03 \\
\hline
\end{tabular}

Source: Author's own elaboration based on CGR $(2013,2015)$.

\section{Tariffs and user fees}

In addition to the fuel tax and vehicle ownership tax, Law No. 7798 allows CONAVI to set tolls in government-operated roads and bridges, excluding those operating under a Public Private Partnership (PPP scheme) or concessions. For the latter, user fees are set in the PPP/concession contracts and validated by ARESEP. There is only one highway operated under concession (Route 27). Government operated toll roads are Route 1 (San Jose-San Ramon), Route 2 (San Jose-Cartago) and Route 32 (San Jose-Limon) 
(Table 8). Tolls have historically been established on political conditions rather than technical criteria and have not been updated since 2002. Given this backdrop, government tolls generate a marginal cash inflow per year of USD7 million (0.01\% of GDP) (CONAVI, 2014).

Table 8. Toll roads in Costa Rica

2014.

\begin{tabular}{|c|c|c|c|c|c|c|}
\hline \multirow[b]{2}{*}{ Route } & \multirow[b]{2}{*}{$\mathrm{Km}$} & \multicolumn{5}{|c|}{ Toll (USD) } \\
\hline & & Cars & $\begin{array}{l}\text { Light } \\
\text { Trucks }\end{array}$ & Buses & $\begin{array}{l}\text { Heavy } \\
\text { Trucks }\end{array}$ & Motorcycles \\
\hline Route 1 (section A) & 15.2 & 0.14 & 0.28 & 0.28 & 0.46 & 0.09 \\
\hline Route 1 (section B) & 40.7 & 0.28 & 0.69 & 0.69 & 1.76 & 0.09 \\
\hline Route 2 & 14.1 & 0.14 & 0.28 & 0.28 & 0.46 & 0.09 \\
\hline Route 32 & 63.6 & 0.46 & 1.39 & 0.69 & 3.47 & 0.09 \\
\hline
\end{tabular}

Source: CONAVI (2014).

\section{Multilateral financial institutions and foreign national development banks}

Although resources from multilateral institutions have been key to developing transportation infrastructure projects, this source is far from sufficient for meeting the country investment needs. As of May $31^{\text {st }}, 2015$, total multilateral funding reached USD 1600 million (2.9\% of GDP). Further, government capacity to use these funds is limited as attested by numerous and long project delays.

By creditor, Inter-American Development Bank (IADB) ranks first (USD810 million), followed by the Central American Bank of Economic Integration (CABEI) and the Corporacion Andina de Fomento (CAF) (Table 9). In addition, the Costa Rican Congress recently approved a USD396 million operation with the Chinesse Eximbank to rebuild and expand a $107 \mathrm{~km}$ section of Route 32, connecting San José with the Caribbean coast. However, this project has been temporarily suspended because of political and technical questions regarding the project preparation and a contract obligation that would require to select a specific Chinese firm as a contractor. 
Table 9. International loans for infrastructure development

As at May $31^{\text {st }}, 2015$

\begin{tabular}{|lcccccc|}
\hline & $\begin{array}{l}\text { First Road } \\
\text { Infrastruct } \\
\text { ure } \\
\text { Programa } \\
\text { (PIV 1) }\end{array}$ & $\begin{array}{l}\text { Bajos de } \\
\text { Chilamate } \\
\text { Vuelta } \\
\text { Kooper } \\
\text { Road } \\
\text { Project }\end{array}$ & $\begin{array}{l}\text { First } \\
\text { Municip } \\
\text { al Road } \\
\text { Program }\end{array}$ & $\begin{array}{l}\text { Transport } \\
\text { Infrastruct } \\
\text { ure } \\
\text { Program }\end{array}$ & $\begin{array}{l}\text { Strategic } \\
\text { Road } \\
\text { Infrastruct } \\
\text { ure } \\
\text { Program }\end{array}$ & $\begin{array}{l}\text { Rehabilitation and } \\
\text { Expansion of Route } \\
\mathbf{3 2}\end{array}$ \\
\hline Amount (USD mil) & 300 & 52.45 & 60 & 450 & 340 & 395.75 \\
\hline Type of infrastructure & Road & Road & Road & Road \& Port & Road & Road \\
\hline Creditor & IADB & CAF & IADB & IADB & CABEI & Jun 2013 \\
\hline $\begin{array}{l}\text { Date of signing } \\
\text { contract }\end{array}$ & Nov 2009 & Feb 2009 & Feb 2011 & Apr 2014 & Apr 2012 \\
\hline Date of Law approval & Sep 2010 & Sep2010 & Oct2011 & Nov 2014 & NA & May 2015 \\
\hline Percentage of Disbursement & $68.5 \%$ & $61.4 \%$ & $25.0 \%$ & $0.0 \%$ & $6.20 \%$ & $0.0 \%$ \\
\hline
\end{tabular}

Note: Credit with China Eximbank is still subject of debate among national authorities.

Source: Ministry of Finance (2015).

\section{Private Investment in Transport Infrastructure}

Private participation in transport infrastructure requires a regulatory and institutional environment conducive to low regulatory and policy uncertainty. There is evidence that a sound and transparent legal and institutional framework allowing for ample consultation with all stakeholders international encourages private participation (Siemiatycki, 2013). Encouraging private sector participation also requires projects with a risk-reward balance aligning public and private sector needs (OECD, 2011).

\section{Costa Rican concession law}

Costa Rican legal framework for private investment in transport infrastructure is governed by the 1998 Law 7762 "General Concession Law of Public Works with Public Services" modified in 2008 (Law 8643). The current legislation governs private participation across different sectors except for energy, telecommunications and pre-existing port facilities. The National Concessions Council (CNC) coordinates and manages concessions (Table 10). 
Table 10. Key elements of Costa Rica's PPP and concession framework

\begin{tabular}{|c|c|c|c|}
\hline \multicolumn{4}{|c|}{ General Concession Law of Public Works with Public Services } \\
\hline Definition & Scope & $\begin{array}{c}\text { Source of } \\
\text { Repayment }\end{array}$ & Main Institution \\
\hline $\begin{array}{l}\text { Contract including design, planning, } \\
\text { financing, construction, } \\
\text { maintenance, expansion or } \\
\text { reconstruction of any public } \\
\text { infrastructure asset. The project } \\
\text { may include the provision of public } \\
\text { services. }\end{array}$ & $\begin{array}{l}\text { Excludes telecommunication } \\
\text { and energy. . Concession of } \\
\text { port infrastructure is limited to } \\
\text { expansion of facilities or } \\
\text { development of new projects. } \\
\text { Maximum contract term of } 50 \\
\text { years. }\end{array}$ & $\begin{array}{l}\text { User charges, } \\
\text { ancillary revenues } \\
\text { related to the project } \\
\text { or government } \\
\text { payments. }\end{array}$ & $\begin{array}{l}\text { National Concession Council: } \\
\text { promotion and coordination of } \\
\text { PPP and concession } \\
\text { contracts; } \\
\text { Ministry of finance: } \\
\text { authorization of tax } \\
\text { exemptions for project } \\
\text { development } \\
\text { Comptroller general: } \\
\text { Concession contracts are } \\
\text { required countersignature by } \\
\text { the Comptroller General of the } \\
\text { Republic of Costa Rica } \\
\text { (CGR). }\end{array}$ \\
\hline \multicolumn{4}{|c|}{ National Concessions Council } \\
\hline Board & Role & Budget & Employees \\
\hline $\begin{array}{c}\text { Minister of Public Works } \\
\text { Minister of Finance } \\
\text { Minister of Planning } \\
\text { President of the Central Bank } \\
\text { Representatives of private sector (1 } \\
\text { from labor organizations, } 1 \text { from the } \\
\text { Federation of Professional Boards, } \\
1 \text { from private sector chambers). }\end{array}$ & $\begin{array}{c}\text { Approval/disapproval of tender } \\
\text { documentation. } \\
\text { Bidder selection. } \\
\text { Sign concession contracts } \\
\text { when central government acts } \\
\text { as the public counterpart. } \\
\text { Control and monitoring of } \\
\text { contracts. }\end{array}$ & $\begin{array}{c}\text { Annual budget of } \\
\text { approximately USD10 } \\
\text { million (USD15 million } \\
\text { for 2015). } \\
\text { Mainly funded (about } \\
\text { 90\%) from central } \\
\text { government budget. } \\
\text { Annual fee on } \\
\text { operating } \\
\text { concessions provides } \\
\text { additional resources } \\
\text { to CNC. }\end{array}$ & $\begin{array}{c}\text { CNC has } 31 \text { active } \\
\text { employees (43 approved). }\end{array}$ \\
\hline
\end{tabular}

Source: Author's elaboration based on Law No. 7762 and CNC (2015).

Thus far only 4 projects have materialised since the concession law was approved almost 20 years ago. These are Route 27, Grain Terminal of Caldera Port, Passenger Terminal of the Liberia International Airport and Moin Container Terminal which was recently started (Table 11). The modernization of Juan Santamaria International Airport and Caldera Port were also developed with private capital, but under the Administrative Contracting Law (No.7494). Other 2 projects, the Metropolitan Electric Train and Route San Jose-San Ramon were suspended against political and media pressure (Box 1). Furthermore, the few projects that moved forward suffered from up to an 11-year delay from the time the bidding process was performed to the beginning of the construction phase. 
ECO/WKP(2016)47

Table 11. Transport infrastructure projects involving private participation during the past 2 decades $1995-2015$.

\begin{tabular}{|c|c|c|c|c|c|}
\hline Project & $\begin{array}{l}\text { Investment } \\
\text { (USD mil) }\end{array}$ & $\begin{array}{l}\text { Contract } \\
\text { Length } \\
\text { (years }\end{array}$ & $\begin{array}{l}\text { Bidding } \\
\text { Process }\end{array}$ & $\begin{array}{c}\text { Started } \\
\text { Construction }\end{array}$ & $\begin{array}{c}\text { Started } \\
\text { Operations }\end{array}$ \\
\hline \multicolumn{6}{|c|}{ General Concession Law } \\
\hline $\begin{array}{l}\text { Route } 27 \text { (San Jose- } \\
\text { Caldera) }\end{array}$ & 360 & 25 & 1998 & 2008 & 2010 \\
\hline $\begin{array}{l}\text { Grain Terminal of Caldera } \\
\text { Port }\end{array}$ & 25 & 25 & 2001 & 2013 & 2015 \\
\hline $\begin{array}{l}\text { Passenger Terminal of the } \\
\text { Liberia Int. Airport }\end{array}$ & 35 & 20 & 2008 & 2010 & 2012 \\
\hline Moin Container Terminal & 956 & 33 & 2010 & 2015 & 2017E \\
\hline $\begin{array}{l}\text { Route } 1 \text { (San Jose-San } \\
\text { Ramón) }\end{array}$ & 524 & 30 & $2002^{2}$ & \multicolumn{2}{|c|}{ Cancelled 2013- } \\
\hline Metropolitan Electric Train & 340 & 30 & 2009 & \multicolumn{2}{|c|}{ Cancelled 2009} \\
\hline \multicolumn{6}{|c|}{ Administrative Contracting Law } \\
\hline $\begin{array}{l}\text { Operation and expansion of } \\
\text { Juan Santamaria Int Airport }\end{array}$ & 138 & 25 & 1998 & 2009 & 2009 \\
\hline Operation of Caldera Port & 5.5 & 20 & 2001 & 2006 & 2006 \\
\hline
\end{tabular}

Source: Author's own elaboration base con CNC (2015) and INCOP (2015).

Overall the legal framework and institutional setting are ill suited to promote private participation in infrastructure. The OECD Principles for the Public Governance of Public-Private Partnerships (OECD, 2012) offers guidance to build a sound governance framework to effectively manage PPPs. Also, the OECD Principles for Private Sector Participation in Infrastructure (OECD, 2007) lists basic rules that can be useful to attract more private investment in infrastructure while also managing the ensuing risks. Table 12 shows that in many respects Costa Rica falls short of these principles and that reforms on several fronts are needed to move towards them.

The followings are the most urgent issues that need to be addressed:

- Unreliable project pipeline. Costa Rica does not have a reliable project pipeline as execution is basically a discretionary decision-making process by political authorities. A pipeline would provide an adequate timeframe to structure and tender the selected projects and increase transparency, thus reducing uncertainty. In addition, a long-term pipeline would strengthen public sector accountability and send a clear sign of government commitment to attract local and foreign investors in transport infrastructure (and not just for isolated projects). As of date, there is no clarity on future projects to be executed under a private finance scheme. Among OECD countries the Australia and United Kingdom offer good example of comprehensive and regularly updated pipelines of infrastructure projects involving private participation (Pisu, Pels and Bottini, 2015).

- Lack of guidelines. As with project prioritization, deciding whether to choose conventional project funding or private participation is susceptible to political and ideological interferences. Costa Rica lacks mandatory guidelines for public sector institutions and no cost-benefit analysis is conducted to decide whether a project is procured by concession or through the traditional procurement scheme.

\footnotetext{
${ }^{2}$ In 1994 was the government first attempt to develop San Jose-San Ramon with private participation.
} 
- Underdeveloped capital market. The long standing practice of funding projects via government budget has inhibited the development of the local financial market for private infrastructure. The Ministry of Finance and Central Bank account for the bulk of bond issuances. Regarding infrastructure, the only publicly traded instruments are related to energy projects from the Costa Rican Institute of Electricity (ICE). However, these issuances are basically ICE-backed bonds, as the investor's return depends on ICE's credit risk and not directly on the energy projects' performance. In 2014, the National Council for the Supervision of the Financial System (CONASSIF) approved new regulation to facilitate infrastructure financing through the capital markets. As of date no project has been funded under this new regulatory framework. Further, there is no policy or guideline concerning government role in enhancing the financial structure of projects involving private participation through for instance guarantees, subordinated debt and subsidies.

- Poor stakeholder involvement. Project acceptance, especially if it involves user fees depends on efficacious and timely communication from the initial stage. In this sense, San José-San Ramón paid the great cost of no having had a clear communications plan explaining ahead of time (Box 1).

\section{Box 1. San Jose-San Ramon project}

San José-San Ramón is a $60.6 \mathrm{~km}$ corridor, part of Costa Rica's Route 1. It communicates San Jose with the Juan Santamaria International Airport and the western region of the Great Metropolitan Area (GAM).

Given the need of a major investment to rehabilitate and expand this corridor, in 2002 the Costa Rican government decided to execute the project through concession. The bidding process started in February, 2002 and only was offer was presented by Consorcio Vial San Jose-San Ramon S.A., a consortium formed by Concesiones Viales de Costa Rica S.A.(subsidiary of Spanish FCC), Itinere Costa Rica S.A., Soares Da Costa Concesiones Costa Rica S.A. and M\&S Concesiones S.A. The USD270 million (USD1.3 maximum one way toll, 25 years) proposal was approved by the CNC in June 2004. The CNC signed the contract in September 2004, countersigned by the CGR in April 2005.

Although the project was expected to break ground in May 2006, it was postponed due to pending land expropriation and public services relocation works by the Costa Rican government. By 2009, in the midst of the global economic crisis, the consortium had not reached the financial close. In 2012, the CNC approved the contract was transfer to a new concessionaire, OAS Central America Investing Limited. The contract with OAS increased total construction costs to USD524 million, as well as the maximum one way toll (USD3.9) and contract length (30 years). After strong pressure from community organizations, political groups and media, in April 2013 the government cancelled the contract, paying OAS USD34.9 million as indemnity for early termination.

Civil organizations proposed the authorities an alternative scheme to develop the project with resources from national banks and pension funds. As of date, the project is still uncertain as there is no clarity on the extent to which the government would have to contribute in terms of cash grants and guarantees.

Source: Vassallo (2015) and MOPT (2013).

- Weak leading institution: CNC has been unsuccessful in promoting and executing Costa Rica's concession policy, mainly due to poor project management and failure to comply with contract deadlines. CNC plays a role akin to the PPP Unit already present in 18 OECD countries. However, unlike CNC, which is a body within MOPT, most of OECD countries' PPP units have been established within the Ministry of Finance or as a subordinate body of this ministry. Only four countries (Chile, Denmark, Hungary and Japan) have PPP units only in line ministries and one country (Greece) has a PPP unit in another body (OECD, 2014a). Also, CNC's board of directors is ill designed and does not appear to contribute to CNC's effectiveness and efficiency (CGR, 2011). CNC's board of directors counts seven members: the minister of public works 
(MOPT), the minister of finance, the minister of planning, the president of the central bank, one representative from private sector chambers, one representative from labor organizations and one representative from the Federation of Professional Boards. The CGR analyzed board members' absence rate in CNC sessions from 2006 to 2010 (CGR, 2011). The ministry of finance was the member with the highest absence rate $(73 \%)$, followed by the president of the central bank $(68 \%)$ and the minister of planning (28\%). Therefore, the main decisions were taken by the minister of public works and the representatives from the private sector.

\section{Table 12. OECD Principles for Private Sector Participation in Infrastructure and Costa Rica's practices}

\begin{tabular}{|c|c|c|}
\hline Principle & OECD Guidelines & Costa Rica \\
\hline \multicolumn{3}{|c|}{ Deciding on public or private provision of infrastructure services } \\
\hline 1 & $\begin{array}{l}\text { The choice by public authorities between public and private provision } \\
\text { should be based on cost-benefit analysis taking into account all } \\
\text { alternative modes or delivery, the full system of infrastructure provision, } \\
\text { and the projected financial and non-financial costs and benefits over the } \\
\text { project lifecycle. }\end{array}$ & $\begin{array}{l}\text { No cost-benefit analyses are performed } \\
\text { in Costa Rica. Choices are is } \\
\text { susceptible to political interference and } \\
\text { changes following government changes. }\end{array}$ \\
\hline 2 & $\begin{array}{l}\text { No infrastructure project-regardless of the degree if private involvement } \\
\text {-should be embarked upon without assessing the degree to which its } \\
\text { costs can be recovered from end-users and, in case of shortfalls, what } \\
\text { other sources of finance can be mobilized. }\end{array}$ & $\begin{array}{l}\text { The role of Ministry of Finance has } \\
\text { been traditionally limited to authorizing } \\
\text { tax exemptions for project } \\
\text { development. }\end{array}$ \\
\hline 3 & $\begin{array}{l}\text { The allocation of risk between private parties and the public sector will } \\
\text { be largely determined by the chosen model of private sector } \\
\text { involvement, including the allocation of responsibilities. The selection of } \\
\text { a particular model and an associated allocation of risk should be based } \\
\text { upon an assessment of the public interest. }\end{array}$ & $\begin{array}{l}\text { Lack of mandatory guidelines for public } \\
\text { sector institutions to decide whether a } \\
\text { project is procured by concession or } \\
\text { through the traditional scheme and how } \\
\text { to allocate risks }\end{array}$ \\
\hline 4 & $\begin{array}{l}\text { Fiscal discipline and transparency must be safeguarded, and the potential } \\
\text { public finance implications of sharing responsibilities for infrastructure } \\
\text { with the private sector fully understood. }\end{array}$ & $\begin{array}{l}\text { Limited involvement of Ministry of } \\
\text { Finance in structuring concessions. }\end{array}$ \\
\hline \multicolumn{3}{|c|}{ Enhancing the enabling institutional environment } \\
\hline 5 & $\begin{array}{l}\text { A sound enabling environment for infrastructure investment, which } \\
\text { implies high standards of public and corporate governance, transparency } \\
\text { and the rule of law, including protection of property and contractual } \\
\text { rights, is essential to attract the participation of the private sector. }\end{array}$ & $\begin{array}{l}\text { Weak leading institution (CNC) and no } \\
\text { clear rules for investors. There are no } \\
\text { standardized contracts; the government } \\
\text { has often missed contract deadlines. }\end{array}$ \\
\hline 6 & $\begin{array}{l}\text { Infrastructure projects should be free from corruption at all levels and in } \\
\text { all project phases. Public authorities should take effective measures to } \\
\text { ensure public and private sector integrity and accountability and } \\
\text { establish appropriate procedures to deter, detect and sanction corruption. }\end{array}$ & $\begin{array}{l}\text { Strong institutional control by the } \\
\text { Comptroller General. }\end{array}$ \\
\hline 7 & $\begin{array}{l}\text { The benefits of private sector participation in infrastructure are enhanced } \\
\text { by efforts to create a competitive environment, including by subjecting } \\
\text { activities to appropriate commercial pressures, dismantling unnecessary } \\
\text { barriers to entry and implementing and enforcing adequate competition } \\
\text { laws. }\end{array}$ & $\begin{array}{l}\text { Barriers to competition are high in the } \\
\text { infrastructure sector; the absence of a } \\
\text { reliable project pipeline and weak } \\
\text { institutional environment have resulted } \\
\text { in limited offers in bidding processes. }\end{array}$ \\
\hline 8 & $\begin{array}{l}\text { Access to capital markets to fund operations is essential to private sector } \\
\text { participants. Restrictions in access to local markets and obstacles to } \\
\text { international capital movements should, taking into account } \\
\text { macroeconomic policy considerations, be phased out. }\end{array}$ & $\begin{array}{l}\text { There are no restrictions to access the } \\
\text { capital market but the capital market is } \\
\text { small The long-standing tradition of } \\
\text { funding projects through government } \\
\text { budget has inhibited its development. }\end{array}$ \\
\hline \multicolumn{3}{|c|}{ Goals, strategies and capacities at all levels } \\
\hline 9 & $\begin{array}{l}\text { Public authorities should ensure adequate consultation with end-users } \\
\text { and other stakeholders including prior to the initiation of an } \\
\text { infrastructure project. }\end{array}$ & $\begin{array}{l}\text { Poor stakeholder management has } \\
\text { resulted in opposition to private } \\
\text { participation and project execution } \\
\text { delays }\end{array}$ \\
\hline 10 & $\begin{array}{l}\text { Authorities responsible for privately-operated infrastructure projects } \\
\text { should have the capacity to manage the commercial processes involved } \\
\text { and to partner on an equal basis with their private sector counterparts. }\end{array}$ & $\begin{array}{l}\text { CNC suffers from human capital } \\
\text { limitations due to non-competitive pay } \\
\text { scale; the Board of Directors does not } \\
\text { contribute to CNC's effectiveness and } \\
\text { efficiency. }\end{array}$ \\
\hline 11 & Strategies for private sector participation in infrastructure need to be & CNC has limited communication and \\
\hline
\end{tabular}




\begin{tabular}{|c|c|c|}
\hline & $\begin{array}{l}\text { understood, and objectives shared, throughout all levels of government } \\
\text { and in all relevant parts of the public administration. }\end{array}$ & $\begin{array}{l}\text { knowledge-sharing with other public } \\
\text { sector institutions. }\end{array}$ \\
\hline 12 & $\begin{array}{l}\text { Mechanisms for cross-jurisdictional co-operation, including at the } \\
\text { regional level, may have to be established. }\end{array}$ & $\begin{array}{l}\text { There is no policy to strengthen local } \\
\text { governments' capacity. }\end{array}$ \\
\hline \multicolumn{3}{|c|}{ Making the public-private co-operation work } \\
\hline 13 & $\begin{array}{l}\text { To optimize the involvement of the private sector, public authorities } \\
\text { should communicate clearly the objectives of their infrastructure policies } \\
\text { and they should put in place mechanisms for consultations between the } \\
\text { public and private partners regarding these objectives as well as } \\
\text { individual projects. }\end{array}$ & $\begin{array}{l}\text { There is no overall infrastructure } \\
\text { strategy, reliable project pipeline, clear } \\
\text { rules and certainty on the continuity of } \\
\text { projects. }\end{array}$ \\
\hline 14 & $\begin{array}{l}\text { There should be full disclosure of all project-relevant information } \\
\text { between public authorities and their private partners, including the state } \\
\text { of pre-existing infrastructure, performance standards and penalties in the } \\
\text { case of non-compliance. The principle of due diligence must be upheld. }\end{array}$ & $\begin{array}{l}\text { No clear rules for information sharing } \\
\text { with the private sector. }\end{array}$ \\
\hline 15 & $\begin{array}{l}\text { The awarding of infrastructure contracts or concessions should be } \\
\text { designed to guarantee procedural fairness, non-discrimination and } \\
\text { transparency. }\end{array}$ & $\begin{array}{l}\text { Lack of credible pipeline, unclear rules } \\
\text { and non-standardized contracts } \\
\text { diminish competition. }\end{array}$ \\
\hline 16 & $\begin{array}{l}\text { The formal agreement between authorities and private sector participants } \\
\text { should be specified in terms of verifiable infrastructure services to be } \\
\text { provided to the public on the basis of output or performance based } \\
\text { specifications. It should contain provisions regarding responsibilities and } \\
\text { risk allocation in the case of unforeseen events. }\end{array}$ & $\begin{array}{l}\text { There are no standardized contracts to } \\
\text { guarantee that these elements are } \\
\text { included. }\end{array}$ \\
\hline 17 & $\begin{array}{l}\text { Regulation of infrastructure services needs to be entrusted to specialized } \\
\text { public authorities that are competent, well-resourced and shielded from } \\
\text { undue influence by the parties to infrastructure contracts. }\end{array}$ & $\begin{array}{l}\text { CNC's difficulties in promoting and } \\
\text { executing Costa Rica's concession } \\
\text { policy are due to poor project } \\
\text { management and failure to comply with } \\
\text { contract deadlines. }\end{array}$ \\
\hline 18 & $\begin{array}{l}\text { Occasional renegotiations are inevitable in long-term partnerships, but } \\
\text { they should be conducted in good faith, in a transparent and non- } \\
\text { discriminatory manner. }\end{array}$ & $\begin{array}{l}\text { Unclear rules encourage contract } \\
\text { renegotiation. }\end{array}$ \\
\hline 19 & $\begin{array}{l}\text { Dispute resolution mechanisms should be in place through which } \\
\text { disputes arising at any point in the lifetime of an infrastructure project } \\
\text { can be handled in a timely and impartial manner. }\end{array}$ & $\begin{array}{l}\text { Dispute resolution mechanisms are } \\
\text { included in contracts but deadlines are } \\
\text { often not specified. }\end{array}$ \\
\hline \multicolumn{3}{|c|}{ Encouraging responsible business conduct } \\
\hline 20 & $\begin{array}{l}\text { Private sector participants in infrastructure should observe commonly } \\
\text { agreed principles and standards for responsible business conduct. }\end{array}$ & $\begin{array}{l}\text { Private sector chambers do not clearly } \\
\text { communicate to stakeholder their } \\
\text { business conduct standards. }\end{array}$ \\
\hline 21 & $\begin{array}{l}\text { Private enterprises should participate in infrastructure projects in good } \\
\text { faith and with a commitment to fulfil their commitments. }\end{array}$ & $\begin{array}{l}\text { Private sector participation is perceived } \\
\text { negative by several citizen and political } \\
\text { sectors. }\end{array}$ \\
\hline 22 & $\begin{array}{l}\text { Private sector participants, their subcontractors and representatives } \\
\text { should not resort to bribery and other irregular practices to obtain } \\
\text { contracts, gain control over assets or win favors, nor should they accept } \\
\text { to be party to such practices in the course of their infrastructure } \\
\text { operations. }\end{array}$ & $\begin{array}{l}\text { Private sector chambers should develop } \\
\text { a code of conduct for the participation } \\
\text { in public infrastructure projects. }\end{array}$ \\
\hline 23 & $\begin{array}{l}\text { Private sector participants should contribute to strategies for } \\
\text { communicating and consulting with the general public, including vis-à- } \\
\text { vis consumers, affected communities and corporate stakeholders, with a } \\
\text { view to developing mutual acceptance and understanding of the } \\
\text { objectives of the parties involved. }\end{array}$ & $\begin{array}{l}\text { Private sector does not always play a } \\
\text { key role in promoting infrastructure } \\
\text { projects (APM Terminals' } \\
\text { communication strategy for the Moin } \\
\text { Container Terminal mark a positive } \\
\text { example). }\end{array}$ \\
\hline 24 & $\begin{array}{l}\text { Private sector participants in the provision of vital services to } \\
\text { communities need to be mindful of the consequences of their actions for } \\
\text { those communities and work, together with public authorities, to avoid } \\
\text { and mitigate socially unacceptable outcomes }\end{array}$ & $\begin{array}{l}\text { System overall does not promote a } \\
\text { trustful partnership between public and } \\
\text { private sector. }\end{array}$ \\
\hline
\end{tabular}

Source: Author's elaboration based on OECD (2007). 


\section{Infrastructure and green growth}

Costa Rica has long-standing commitment to promote economic growth while preserving environmental resources. In this regard, in 2009 the country pledged to start becoming carbon neutral by 2021. The most significant obstacle Costa Rica will face to achieve this ambitious target comes from the transport sector as it accounts for about $70 \%$ of carbon emissions. The transport sector relies exclusively on fossil fuels as a source of energy. More than $70 \%$ of the national energy consumption comes from oil derivatives, primarily driven by the transportation sector (59\% of total energy demand) (Figure 5).

\section{Figure 5 . Breakdown of energy consumption by sector and product}

2004-2013
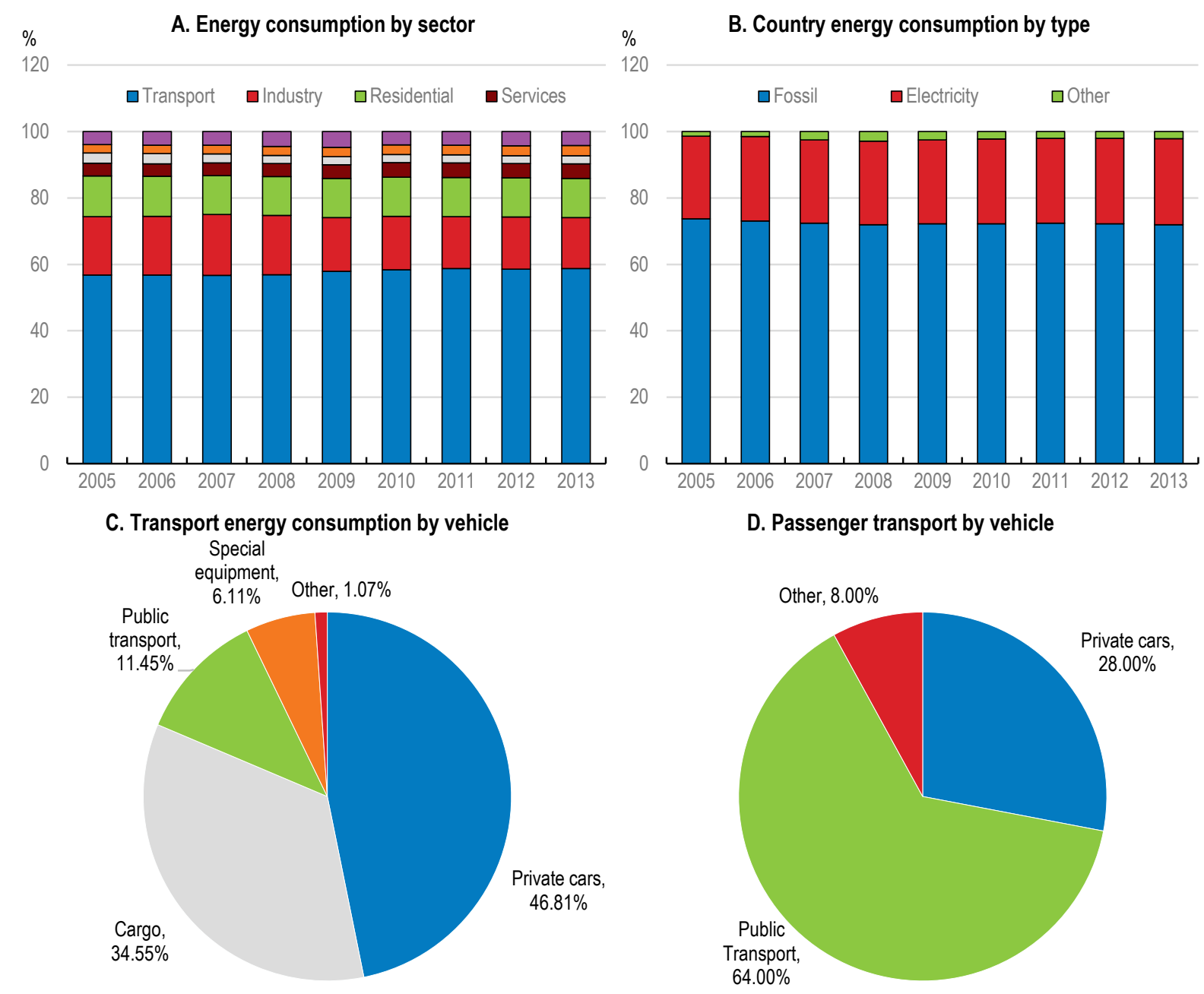

Source: Author's elaboration based on Programa Estado de la Nación (2014), Sectorial Energy Office -DSE- (2012) and CGR (2014). 
Costa Rica still lacks a solid national policy on clean transportation encompassing all of the sector's institutions. The OECD/ITF Transport Outlook 2015 underlines that the alignment of policies toward public transportation-oriented urbanization, combined with world-class standards of vehicle emission control, can reduce carbon intensity in urban mobility, as well as premature mortality caused by air pollutants (OECD, 2015b). Along these lines, INCOFER is on the early stages of preparing a major project to develop a rapid train system in the GAM. The project was officially established as a government priority in May 2015.

The project is intended to connect the major cities of Alajuela, Heredia, Cartago and San José, representing around 2.5 million potential users. The target population is mainly all the current users of public transportation. The plan is divided in 3 phases, with an estimated total budget of USD 1400 million and a completion date set for October 2022 (Table 12). The May 2016 date for Phase 1 will unlikely be accomplished, as there is still no clarity on the financing and operation scheme.

The economic, financial and social evaluation of the project will be determined under a feasibility study (INCOFER, 2014). In addition, INCOFER authorities expect Congress to approve Bill 18,525 "Strengthening of the INCOFER and promotion of interurban electric train for the GAM". This new legal framework is expected to provide INCOFER with more financial flexibility, by allowing the institutions to develop PPPs as well as capturing value from its assets (primarily land).

Table 13. INCOFER Rapid Train System Project for San Jose great metropolitan area

\begin{tabular}{lcc}
\hline \multicolumn{1}{c}{ Phase } & $\begin{array}{c}\text { Investment (USD } \\
\text { mil) }\end{array}$ & Conclusion Date \\
\hline Phase 1: Modernization San José-Alajuela & 120 & May 2016 \\
Phase 2: New viaduct and railway San José-Paraiso & 500 & May 2018 \\
(Cartago) & 780 & Oct 2022 \\
Phase 3: New viaduct and railway San José-Alajuela & TBD & TBD \\
Phase 4: San Ramón (Alajuela)- Puntarenas (Orotina) & 1,400 & NA \\
Total & &
\end{tabular}

Source: INCOFER (2014, 2015). 


\section{BIBLIOGRAPHY}

Ahrend, R. and A. Schumann (2014), "Approaches to Metropolitan Area Governance: A Country Overview”, OECD Regional Development Working Papers, 2014/03, OECD

Academia de Centroamerica (2014), La gestión de la infraestructura pública en Costa Rica: el caso de la red vial nacional, San Jose.

Comptroller General of the Republic of Costa Rica - CGR- (2010), Informe Técnico: Proyecto de Ley de Presupuesto de la República 2011, Comptroller General of the Republic of Costa Rica, San Jose.

CGR (2011), Informe de Fiscalización sobre la Gestión del Consejo Nacional de Concesiones para el Desarrollo de las Concesiones y su Financiamiento Local, Comptroller General of the Republic of Costa Rica, San Jose.

CGR (2011), Memoria Anual 2010, Comptroller General of the Republic of Costa Rica, San Jose.

CGR (2011), Informe Técnico: Proyecto de Ley de Presupuesto de la República 2012, Comptroller General of the Republic of Costa Rica, San Jose.

CGR (2011), Sector de Infraestructura y Transportes: Hacia un Modelo de Gestión de Políticas Públicas. Comptroller General of the Republic of Costa Rica, San Jose.

CGR (2012), Memoria Anual 2011, Comptroller General of the Republic of Costa Rica, San Jose.

CGR (2012), Informe Técnico: Proyecto de Ley de Presupuesto de la República 2013, Comptroller General of the Republic of Costa Rica, San Jose

CGR (2013), Memoria Anual 2012, Comptroller General of the Republic of Costa Rica, San Jose.

CGR (2013), Informe Técnico: Proyecto de Ley de Presupuesto de la República 2014, Comptroller General of the Republic of Costa Rica, San Jose.

CGR (2014a), Informe de Auditoría Operativa sobre la eficacia y eficiencia en la prestación de servicios de transporte de pasajeros, modalidad ferrocarril, en el Gran Área Metropolitana, Comptroller General of the Republic of Costa Rica, San Jose.

CGR (2014b), Memoria Anual 2013, Comptroller General of the Republic of Costa Rica, San Jose.

CGR (2014c), Informe Técnico: Proyecto de Ley de Presupuesto de la República 2015, San Jose.

CGR (2015), Memoria Anual 2014, Comptroller General of the Republic of Costa Rica, San Jose.

CGR (2015), Informe Técnico: Proyecto de Ley de Presupuesto de la República 2016. San Jose. 
CONAVI (2015), Informe de Evaluación Annual. Available at http://www.conavi.go.cr/wps/wcm/connect/db873339-0af1-417e-b53d6a80705e2bf7/Diciembre+2014+informe +de+Gesti\%C3\%B3n+anual+2014+-+20ene2015+$. p d f ? M O D=A J P E R E S$

Costa Rican Central Bank - BCCR - (2015), Revisión Programa Monetario 2015-2016, Banco Central Costa Rica, San Jose.

Costa Rican Institute for the Pacific Ports -INCOP- (2015), Información sobre puertos y concesiones, available at http://www.incop.go.cr/incop_modelo_de_fiscalizacion.php, San Jose.

Economic Commission for Latin America and the Caribbean (2014), Base de datos de inversiones en infraestructura económica en América Latina y el Caribe, 1980-2012, Economic Commission for Latin America and the Caribbean, Santiago de Chile.

Estache and Garsous (2012), The impact of infrastructure on growth in developing economies, International Finance Corporation -IFC-. Washington DC, United States.

Ministry of Finance (2015), Créditos Externos del Gobierno Central para el Desarrollo de Infraestructura: Sector Transporte e Infraestructura, Ministry of Finance, San Jose.

Ministry of Planning and Economic Policy -MIDEPLAN- (2007), Manual Explicativo de los Organigramas del Sector Público Costarricense, Ministry of Planning and Economic Policy, San José.

MIDEPLAN (2010), Guía Metodológica General para la Identificación, Formulación y Evaluación de Proyectos de Inversión Pública, Ministry of Planning and Economic Policy, San José.

MIDEPLAN (2010), Sector Público Costarricense y su organización, Ministry of Planning and Economic Policy, San José.

MIDEPLAN (2011), Estructuras Organizacionales: Instituciones Públicas Costarricenses, Ministry of Planning and Economic Policy, San José.

MIDEPLAN (2012), Guía Metodológica para la Identificación, Formulación y Evaluación de Proyectos de Infraestructura Vial en Costa Rica, Ministry of Planning and Economic Policy, San José.

MIDEPLAN (2013), Costa Rica 2030: Objetivos del Desarrollo Nacional, Ministry of Planning and Economic Policy, San José.

MIDEPLAN (2014), Organigrama del Sector Público Costarricense, Ministry of Planning and Economic Policy, San José.

MIDEPLAN (2014), Plan Nacional de Desarrollo 2015-2018 “Alberto Cañas Escalante”, Ministry of Planning and Economic Policy, San José.

Ministry of Public Works - MOPT- (2011), Anuario Estadístico del Sector Transporte e Infraestructura 2010, Ministry of Public Works, San Jose.

MOPT (2011), Plan Nacional de Infraestructura 2011-2035, Ministry of Public Works, San Jose. 
MOPT (2013), Corredor San José-San Ramón: Descripción del proyecto y sus beneficios para los usuarios, Ministry of Public Works, San Jose.

MOPT (2014), Anuario Estadístico del Sector Transporte e Infraestructura 2013, Ministry of Public Works, San Jose.

National Concessions Council -CNC- (2015), Challenges of a PPP Program, Presentation to OECD seminar in San Jose on the $10^{\text {th }}$ of June 2015.

National Laboratory of Materials and Structural Models of the University of Costa Rica LANAMMEUCR- (2015), Informe de Evaluación de la Red Vial Nacional Pavimentada de Costa Rica Años 2014-2015, National Laboratory of Materials and Structural Models of the University of Costa Rica, San José.

National Railway Institute -INCOFER- (2014), Ficha Técnica del Proyecto: Sistema de Transporte Rápido de Pasajeros del Gran Área Metropolitana, National Railway Institute, San Jose.

INCOFER- (2015), Aporte del INCOFER al Transporte Público: En el contexto de la movilidad de personas en el GAM, National Railway Institute San Jose.

INCOFER (2015), Sistema TRP: Ponencia del Presidente Ejecutivo, National Railway Institute, San Jose.

National Road Council -CONAVI- (2014), Información sobre Administración de Peajes, National Road Council, San Jose.

CONAVI (2014), Presupuesto Ordinario 2015, National Road Council, San Jose.

National University of Costa Rica (2007), Inventario de Emisiones de Contaminantes Criterio del Aire. Heredia.

OECD (2007), OECD Principles for Private Sector Participation in Infrastructure. OECD Publishing, Paris.

OECD (2012), OECD Principles for Public Governance of Public-Private Partnerships, OECD Publishing, Paris.

OECD (2013), Spending on Transport Infrastructure 1995-2011: Trends, Policies, and Data, OECD Publishing, Paris.

OECD (2013), OECD Investment Policy Reviews: Costa Rica 2013, OECD Publishing, Paris.

OECD (2014a), Budgeting Practices and Procedures in OECD Countries, OECD Publishing, Paris.

OECD (2014b), OECD Regional Outlook 2014: Regions and Cities: Where Policies and People Meet, OECD Publishing, Paris.

OECD (2015a), Governing the City, OECD Publishing, Paris.

OECD- (2015b), ITF Transport Outlook 2015, OECD Publishing, Paris.

OECD (2016), OECD Economics Survey: Costa Rica, 2016, OECD Publishing, http://dx.doi.org/10.1787/eco_surveys-cri-2016-en 


\section{ECO/WKP(2016)47}

Pisu, M., P. Hoeller and I. Joumard (2012), "Options for Benchmarking Infrastructure Performance", OECD Economics Department Working Papers, No. 956, OECD Publishing Paris.

Pisu, M., B. Pels and N. Bottini (2015), "Improving Infrastructure in the United Kingdom", OECD Economics Department Working Papers No. 1244, OECD Publishing, Paris.

Programa Estado de la Nación (2014), Estado de la Nación en Desarrollo Humano Sostenible: Un análisis amplio y objetivo sobre la Costa Rica que tenemos a partir de indicadores más actuales (2013), Programa Estado de la Nación, available at http://estadonacion.or.cr/..

Sectorial Energy Office, Ministry of Environment and Energy (2012), Balance Energético Nacional de Costa Rica 2011, Ministry of Environment and Energy, San Jose.

Vassallo, Jose Manuel (2015), Asociación Público Privada en América Latina: Aprendiendo de la Experiencia, Corporacion Andina de Fomento, Bogotá, Colombia.

World Bank (2012), Global Development Indicators 2011, World Bank Group, Washington DC, United States.

World Economic Forum - WEF- (2014), The Global Competitiveness Report 2014-2015, World Economic Forum, Geneva.

WEF (2015), The Global Competitiveness Report 2015-2016, World Economic Forum, Geneva. 